\title{
Molecular Characterization of Brucella melitensis Field Isolates by Bruce- Ladder Multiplex PCR
}

\author{
B.R. Sumathi ${ }^{1 *}$, B.M. Veeregowda ${ }^{2}$, S.M. Byregowda ${ }^{1}$, D. Rathnamma ${ }^{2}$, \\ Shrikrishna Isloor ${ }^{2}$, Rajeswari Shome ${ }^{3}$ and H.D. Narayanaswamy ${ }^{2}$
}

${ }^{1}$ Institute of Animal Health and Veterinary Biologicals, ${ }^{2}$ Department of Microbiology, Veterinary College, KVAFSU, Hebbal, Bengaluru-560024, Karnataka, India

${ }^{3}$ Indian Council of Agricultural Research-National Institute of Veterinary Epidemiology and Disease Informatics (ICAR-NIVEDI), Post Box No. 6450, Yelahanka, Bengaluru-560064, Karnataka, India

*Corresponding author

\section{A B S T R A C T}

\section{Keywords}

Brucellosis,

Brucella melitensis,

Bruce-ladder

multiplex PCR and

Amplification

profile

Article Info

Accepted:

07 December 2018

Available Online:

10 January 2019
Brucellosis still remains an infectious, highly contagious and re-emerging endemic zoonosis especially in the Mediterranean and Middle-East regions of the world involving many countries including India where it constitutes occupational hazard (Shakerian et al., 2013 and Khamesipour et al., 2014). It also poses a serious threat to livestock economy by causing abortion, loss of offspring, infertility and reduction in milk yield. The prevalence of brucellosis in animal reservoirs is an evidence of its prevalence in human population and control of animal brucellosis is the key to its control in humans. Early diagnosis is essential to minimise the spread of the disease besides public health importance. In the present study molecular characterization of five Brucella melitensis isolates was carried out through Bruce-ladder multiplex PCR and compared with Brucella abortus, Brucella melitensis and Brucella suis vaccine and challenge strains. The amplification profile confirmed the isolates as Brucella melitensis and there was a significant difference among these field isolates with that of reference vaccine strains and the amplicons of all the field isolates were similar to amplicons of reference challenge strain, Brucella melitensis 16M.

\section{Introduction}

Brucellosis in India is very common but often a neglected disease (Renukaradhya et al., 2002). Caprine and ovine brucellosis caused by $B$. melitensis is widespread in India due to frequent mixing of flocks while grazing and trading (Smits and Kadri, 2005) and is the major cause of abortion in small ruminants imposing economic loss due to an adverse effect on total animal protein supplies and severe hazard to human health (Abeer et al., 2003).

The human brucellosis results mainly due to 
consumption of contaminated milk, meat, exposure to animal reservoirs. Due to high rates of brucellosis in sheep and goats, socioeconomic status of the risk group and higher pathogenicity of $B$. melitensis among all the Brucella species, makes this organism being most frequently isolated from humans (OIE, 2008).

Since, there is no licensed human vaccine and B. melitensis primarily infect sheep and goats, the prevention of human brucellosis largely depends upon the prevention and control of ovine and caprine brucellosis by prophylactic and sanitary measures in endemic areas (OIE, 2009). An accurate diagnostic and typing procedure for identification of the different species is of great epidemiological importance to institute control strategies.

Several multiplex PCRs have been described for identification of Brucella at the species level and partly at the biovar level using different primer combinations. The multiplex PCR, called AMOS PCR for Brucella abortus, B. melitensis, B. ovis and B. suis, was published in 1994 where they have used five primers to identify Brucella at the species level (Bricker and Halling, 1994). This method could detect selected biovars of 4 species of Brucella; biovars 1, 2, and 4 of $B$. abortus; all 3 biovars of $B$. melitensis; biovar 1 of B. suis; and biovar 1 of B. ovis but unable to differentiate individual biovars within a species. The PCR was used to evaluate animal field samples and was found to be in 100 per cent agreement with the conventional biotyping methods.

A multiplex PCR using 8 multi-locus variable number tandem repeat analysis (MLVA) primers was able to distinguish $B$. melitensis from other Brucella species and allowed strain typing (Rees et al., 2009). More recently, a multiplex PCR assay (Bruce-ladder) has been used to identify all Brucella sp. at genus level, including 6 six terrestrial species, the marine species of Brucella, and the vaccine strains S19, RB51, and Rev. 1 (Lopez-goni et al., 2008). Based on the Bruce-ladder PCR, an improved multiplex PCR was developed that differentiates all 9 currently recognized Brucella species, including the recently described species $B$. microti, $B$. inopinata, $B$. ceti and $B$. pinnipedialis. The method was used to identify all known Brucella strains and their biotypes in one test (Mayer-scholl et al., 2010).

The present study reports the molecular characterization of five Brucella melitensis isolates which recovered from 18 different sheep and goat farms in Karnataka suspected to have brucellosis which were confirmed by AMOS multiplex PCR and compared with reference vaccine and challenge strains of Brucellae by employing Bruce- ladder multiplex PCR.

\section{Materials and Methods}

\section{Strains and growth conditions}

The reference bacterial strains viz., Brucella abortus S19, B. abortus 544, Brucella melitensis Rev 1, Brucella melitensis 16M and B. suis 1330, mono-specific $\mathrm{A}$ and $\mathrm{M}$ antiserum, Pasteurella multocida P52 were procured from Division of Biological Standardization, Indian Veterinary Research Institute, Izatnagar, Uttar Pradesh. The five field isolates recovered from 18 different brucellosis suspected sheep and goats farms located in four different districts of Karnataka, India, were confirmed by Biochemical tests, group specific and species specific PCR.

Brucella strains were grown in Brucella selective broth (Difco) at $37^{\circ} \mathrm{C}$ for $48 \mathrm{~h}$. Pasteurella multocida P52 was grown on standard nutrient broth at $37^{\circ} \mathrm{C}$ for $24 \mathrm{~h}$.

Genomic DNA was isolated from reference 
strains and suspected Brucella cultures using Genomic DNA extraction kit from M/s Qiagen, USA as per manufacturer's instructions. The purity of the DNA extracted was assessed using Quibit assays M/s Invitrogen, Singapore as per manufacturer's instructions.

\section{Bruce-ladder multiplex PCR}

The Bruce-ladder multiplex PCR assay target for identical genes conserved for each species of Brucella was carried out using 8 pairs of oligonucleotides primers and thermal cycling conditions as per the method described by Lopez-Goni et al., (2008).

The Bruce-ladder is a new multiplex PCR assay for differentiating the various Brucella species and strains in their high degree of genetic homology. Bruce-ladder identification was based on the of eight amplicons, $1682 \mathrm{bp}$, 450 bp, 1071 bp, 794 bp, 587 bp, 272 bp 218 bp and 152 bp by PCR.

Briefly, the Bruce-ladder multiplex PCR was performed with a reaction mixture containing $15 \mathrm{ng}$ of extracted DNA of each strain, 2X Dream taq master mix $12.5 \mu 1,0.3 \mu \mathrm{l}$ of each individual $10 \mu \mathrm{M}$ primers and made the final volume of $25 \mu \mathrm{l}$ with nuclease free water. The thermal cycling conditions include an initial denaturation at $94{ }^{\circ} \mathrm{C}$ for $7 \mathrm{~min}$, followed by 25 cycles of template denaturation at $94{ }^{\circ} \mathrm{C}$ for $60 \mathrm{~s}$, primer annealing at $64{ }^{\circ} \mathrm{C}$ for $45 \mathrm{~s}$ and primer extension at $72{ }^{\circ} \mathrm{C}$ for $3 \mathrm{~min}$, followed by a final extension at $72{ }^{\circ} \mathrm{C}$ for $10 \mathrm{~min}$. The amplified products were resolved by electrophoresis using a 1.5 per cent agarose gel and followed by staining with ethidum bromide.

\section{Results and Discussion}

The amplification profile for Brucella field isolates and reference strains obtained were shown in Figure 1. The reference strain yielded amplicons as described by (GarciaYoldi et al., 2006) and Lopez-Goni et al., (2008). The amplicon size, DNA target and sources of genetic differences is listed in the Table 1.

The Bruce-ladder multiplex PCR targeting DNA from Brucella abortus 544 strain yielded five fragments, of 1,682, 794, 587, 450 and 152 bp (Lane 8; Fig. 1) in size, an additional amplicon of 1071 bp was noticed in $B$. melitensis 16M (Lane 7). Similarly, $B$. suis 1330 yielded an extra amplicon of $272 \mathrm{bp}$ size. Whereas the vaccine strain, B. abortus S19 did not yield $587 \mathrm{bp}$ fragments which is otherwise common to all Brucella strains tested, Finally B. melitensis Rev 1 vaccine strain yielded an additional fragment of 218 $\mathrm{bp}$, which readily distinguished $B$. melitensis Rev 1 from other B. melitensis strains (Fig. 1). The amplicon $218 \mathrm{bp}$ accounts for gene encoding the ribosomal protein S12, rpsL. In Rev 1 vaccine strain there is chromosomally acquired streptomycin resistance is frequently due to mutations in the gene encoding the ribosomal protein S12, rpsL. Nucleotide sequencing revealed one mutation in the rps $L$ gene of vaccine strain Rev.1 compared to that of reference strain $16 \mathrm{M}$ leading to an amino acid Pro-to-Leu change at codon position 91 (Pro91Leu) (Cloeckaert et al., 2002).

All the field isolates yielded similar banding pattern as B. melitensis $16 \mathrm{M}$. There is lack of additional fragment $218 \mathrm{bp}$ in all the field isolates too, which confirms streptomycin susceptibility in these strains. The assay could differentiate field isolate from reference strain and vaccine strain, the $B$. melitensis Rev 1 . In the present investigation too, this technique yielded lucid results, in differentiating $B$. melitensis field isolates from $B$. melitensis Rev 1 , B. abortus S19, B. melitensis 16M, B. abortus 544 and B. suis 1330 (Fig. 1). In the present study all the five isolates recovered from Brucella affected sheep and goats were confirmed as $B$. melitensis which revealed a 
banding pattern similar to challenge strain $B$. melitensis 16M. Ovine and Caprine brucellosis caused by $B$. melitensis is widespread in India and its relative importance varies with the geographical region influenced by husbandry practices, availability of susceptible animal population, frequent mixing of flocks during grazing and inter-state trade of animals. The major advantage of the Bruce-ladder PCR assay was that it could identify and differentiate all the Brucella species and the vaccine strains in one go.

Table.1 Oligonucleaotides used in Bruce-ladder multiplex PCR Assay with target gene and target protein amplified (López-Gon i et al., 2008)

\begin{tabular}{|c|c|c|c|c|}
\hline Primer & Sequence $\left(5^{\prime}-3^{\prime}\right)$ & $\begin{array}{l}\text { Amplicon } \\
\text { Size (bp) }\end{array}$ & DNA target & $\begin{array}{l}\text { Source of genetic } \\
\text { differences }\end{array}$ \\
\hline $\begin{array}{l}\text { BMEI0 } \\
998 f\end{array}$ & $\begin{array}{l}\text { ATC C TA TTG CCC CGA } \\
\text { TAA GG }\end{array}$ & \multirow[t]{2}{*}{1,682} & \multirow{2}{*}{$\begin{array}{l}\text { Gene } \\
\text { WboA } \\
\text { Glycosyltransferase }\end{array}$} & \multirow{2}{*}{$\begin{array}{l}\text { IS711 insertion in } \\
\text { BMEI0998 in B. } \\
\text { abortus RB51 and } \\
\text { deletion of } 15,079 \text { bp in } \\
\text { BMEI0993-- } \\
\text { BMEI1012 in B. ovis }\end{array}$} \\
\hline $\begin{array}{l}\text { BMEI0 } \\
997 \mathrm{r}\end{array}$ & $\begin{array}{l}\text { GCT TCG CAT TTT CAC } \\
\text { TGT AGC }\end{array}$ & & & \\
\hline $\begin{array}{l}\text { BMEIO } \\
535 f\end{array}$ & $\begin{array}{l}\text { GCG CAT TCT TCG GTT } \\
\text { ATG AA }\end{array}$ & \multirow[t]{2}{*}{450} & \multirow{2}{*}{$\begin{array}{l}\text { gene } b p 26 \\
\text { Immunodominant } \\
\text { antigen, }\end{array}$} & \multirow{2}{*}{\begin{tabular}{ll}
\multicolumn{2}{l}{ IS711 insertion in } \\
BMEI0535-BMEI0536 \\
in Brucella & strains \\
isolated from & marine \\
mammals &
\end{tabular}} \\
\hline $\begin{array}{l}\text { BMEIO } \\
536 \mathbf{r}\end{array}$ & $\begin{array}{l}\text { CGC AGG CGA AAA CAG } \\
\text { CTA TAA }\end{array}$ & & & \\
\hline $\begin{array}{l}\text { BMEII } \\
0843 f\end{array}$ & $\begin{array}{l}\text { TTT ACA CAG GCA ATC } \\
\text { CAG CA }\end{array}$ & \multirow[t]{2}{*}{1071} & \multirow{2}{*}{$\begin{array}{l}\text { gene omp } 31 \\
\text { Outer membrane } \\
\text { protein, }\end{array}$} & \multirow{2}{*}{$\begin{array}{l}\text { Deletion of } 25,061 \text { bp in } \\
\text { BMEII826- } \\
\begin{array}{l}\text { BMEII0850 in } \\
\text { abortus }\end{array}\end{array}$} \\
\hline $\begin{array}{l}\text { BMEII } \\
\text { 0844r }\end{array}$ & $\begin{array}{l}\text { GCG TCC AGT TGT TGT } \\
\text { TGA TG }\end{array}$ & & & \\
\hline $\begin{array}{l}\text { BMEI } \\
1436 f\end{array}$ & $\begin{array}{l}\text { ACG CAG ACG ACC TTC } \\
\text { GGT AT }\end{array}$ & \multirow[t]{2}{*}{794} & \multirow[t]{2}{*}{$\begin{array}{l}\text { Polysaccharidde } \\
\text { deacetylase }\end{array}$} & \multirow[t]{2}{*}{$\begin{array}{l}\text { Deletion of } 976 \text { bp in } \\
\text { BMEI1435 in B. canis }\end{array}$} \\
\hline $\begin{array}{l}\text { BMEI } \\
1435 r\end{array}$ & $\begin{array}{l}\text { TTT ATC CAT CGC CCT } \\
\text { GTC AC }\end{array}$ & & & \\
\hline $\begin{array}{l}\text { BMEII } \\
\text { 0428f }\end{array}$ & $\begin{array}{l}\text { GCC GCT ATT ATG TGG } \\
\text { ACT GG }\end{array}$ & \multirow[t]{2}{*}{587} & \multirow{2}{*}{$\begin{array}{l}\text { gene } \operatorname{eryC} \\
\text { Erythritol catabolism, } \\
\text { (erythrulose-1 } \\
\text { phosphate } \\
\text { dehydrogenas) }\end{array}$} & \multirow{2}{*}{$\begin{array}{l}\text { Deletion of } 702 \text { bp in } \\
\text { BMEII0427- } \\
\text { BMEII0428 in } \\
\text { B. abortus S19 }\end{array}$} \\
\hline $\begin{array}{l}\text { BMEII } \\
0428 \mathrm{r}\end{array}$ & $\begin{array}{l}\text { AAT GAC TTC ACG GTC } \\
\text { GTT CG }\end{array}$ & & & \\
\hline $\begin{array}{l}\text { BR095 } \\
\text { 3f }\end{array}$ & $\begin{array}{l}\text { GGA ACA CTA CGC CAC } \\
\text { CTT GT }\end{array}$ & \multirow[t]{2}{*}{272} & \multirow[t]{2}{*}{$\begin{array}{l}\mathrm{ABC} \text { transporter } \\
\text { binding protein }\end{array}$} & \multirow{2}{*}{$\begin{array}{l}\text { Deletion of } 2,653 \text { bp in } \\
\text { BR0951-BR0955 in } B . \\
\text { melitensis and } B . \\
\text { abortus }\end{array}$} \\
\hline $\begin{array}{l}\text { BR095 } \\
\text { 3r }\end{array}$ & $\begin{array}{l}\text { GAT GGA GCA AAC GCT } \\
\text { GAA G }\end{array}$ & & & \\
\hline $\begin{array}{l}\text { BMEI } \\
0752 f\end{array}$ & $\begin{array}{l}\text { CAG GCA AAC CCT CAG } \\
\text { AAG C }\end{array}$ & \multirow[t]{2}{*}{218} & \multirow{2}{*}{$\begin{array}{l}\text { gene } r p s L \\
\text { Ribosomal protein } \\
\text { S12, }\end{array}$} & \multirow{2}{*}{$\begin{array}{l}\text { Point mutation in } \\
\text { BMEI0752 in } \\
\text { melitensis Rev.1 }\end{array}$} \\
\hline $\begin{array}{l}\text { BMEI0 } \\
752 \mathrm{r}\end{array}$ & $\begin{array}{l}\text { GAT GTG GTA ACG CAC } \\
\text { ACC AA }\end{array}$ & & & \\
\hline $\begin{array}{l}\text { BMEII } \\
\text { 0987f }\end{array}$ & $\begin{array}{l}\text { CGC AGA CAG TGA CCA } \\
\text { TCA AA }\end{array}$ & \multirow[t]{2}{*}{152} & \multirow{2}{*}{$\begin{array}{l}\text { Transcriptional } \\
\text { regulator, CRP } \\
\text { family }\end{array}$} & \multirow{2}{*}{$\begin{array}{l}\text { Deletion of } 2,203 \text { bp in } \\
\text { BMEII0986- } \\
\text { BMEII0988 in } \\
\text { B. neotomae }\end{array}$} \\
\hline $\begin{array}{l}\text { BMEII } \\
\text { 0987r }\end{array}$ & $\begin{array}{l}\text { GTA TTC AGC CCC CGT } \\
\text { TAC CT }\end{array}$ & & & \\
\hline
\end{tabular}


Fig.1 Amplification profile of Brucella field isolates and reference strains by Bruce- ladder multiplex PCR

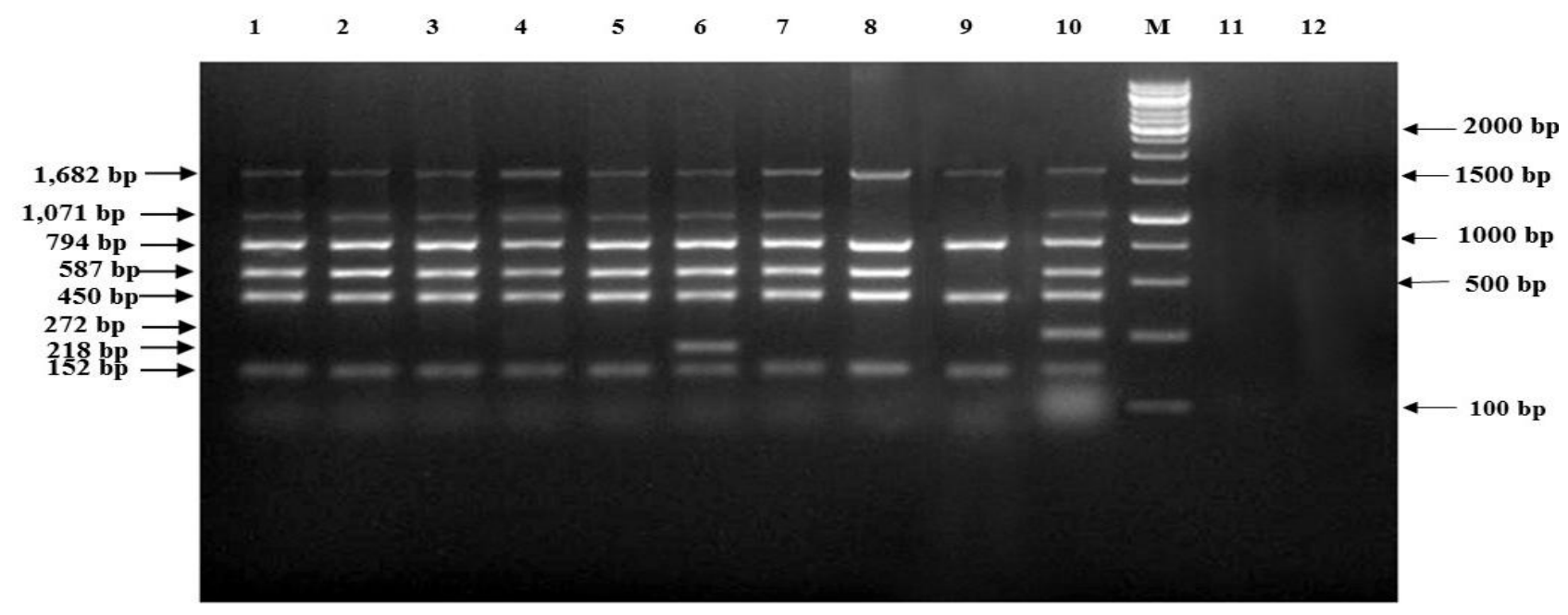

Lanes 1 to 5 : $B$. melitensis field isolates,

Lane 6 : $B$. melitensis Rev 1

Lane 7 : B. melitensis $16 \mathrm{M}$

Lane 8 : $B$. abortus 544

Lane 9 : B. abortus $\mathrm{S19}$

Lane 10 : $B$. suis 1330

Lane M : 3 kb ladder.

Lane 11 : Pasteurella multocida P52 DNA (Negative control)

Lane 12: No template control

Furthermore, it can also detect DNA from $B$. canis, B. neotomae, B. abortus biovars 3, 5, 6, and 9 , and $B$. suis biovars $2,3,4$, and 5 as reported by Lopez-Goni et al., (2008). This method was used to identify 7 epidemiologically-linked clusters of $B$. melitensis and the source of a laboratoryacquired infection. The assay was found to be practical for technical and economical reasons.

In conclusion, in the present study all the five isolates recovered from Brucella affected sheep and goats were further identified and confirmed as $B$. melitensis which were resulted banding pattern similar to challenge strain B. melitensis $16 \mathrm{M}$. Further the study ruled out the infections that might have resulted due to any of the vaccine strains. Since there is no effective vaccine against sheep and goat brucellosis in India, extensive studies need to be carried out by including different geographical areas of the country with varied endemicity to establish the prevalence of $B$. melitensis infections for instituting the effective control strategies to minimise the disease and intern further spread to public.

\section{References}

Abeer, H.A., Shawkat, Q. L. and Al-Tarazi, Y., 2003. Epidemiology of ovine brucellosis in Awassi sheep in northern Jordan. Prev. Vet. Med., 60:297-306.

Bricker, B. J. and Halling, S. M., 1994. Differentiation of Brucella abortus biovar (1, 2, and 4), Brucella melitensis, Brucella ovis and Brucella suis biovar 1 by PCR. J. Clin. Microbiol., 32: 26602666.

Cloeckaerta, A, Grayonb, M and Grépinetb, 
O., 2002. Identification of Brucella melitensis vaccine strain Rev. 1 by PCRRFLP based on a mutation in the rpsL gene. Vaccine. 2546-2550.

Garcia-yoldi d, Marin, C. M., Demiquel, M. J., Munoz, P. M., Vizmanos, J. L., and Lopez-gooni, J., 2006. Multiplex PCR assay for identification and differentiation of all Brucella spp. and the vaccine strains $B$. abortus S19, RB51 and B. melitensis Rev 1. Clin. Chem., 52(4): 779-781.

Khamesipour, F. Rahimi, E., Shakerian, A., Doosti, A., Momtaz, H., 2014. Molecular Study Of The Prevalence Of Brucella Abortus And Brucella Melitensis In The Blood And Lymph Node Samples Of Slaughtered Camels By Polymerase Chain Reaction (Pcr) In Iran. $\quad$ https://doi.org/10.2478/acve2014-0023.

Lopez-Goni, I., Garcia-Yoldi, D., Marin, C. M., De-Miguel, M. J., Munoz, P. M., Blasco, J. M., Jacques, I., Grayon, M., Cloeckaert, A., Ferreira, A. C., Cardoso, R., Correa, M. I., D-Esa, Walravens, K., Albert, D. and Garin-Bastuji, B., 2008. Evaluation of a multiplex PCR assay (Bruce-ladder) for molecular typing of all Brucella species, including the vaccine strains. J. Clin. Microbiol., 46: 3484-3487.

Mayer-scholl, A., Draeger, A., Gollner C.,
Scholz, H. C. and Nockler, K., 2010. Advancement of a multiplex PCR for the differentiation of all currently described Brucella species. J. Microbial. methods. 80:112-4.

OIE Manual of standards for diagnostic tests and vaccines. 2008. Bovine brucellosis, OIE, Paris, pp: 624-659.

OIE, 2009. Manual of Diagnostic Tests and Vaccines for Terrestrial Animals OIE (Ed.) Caprine and Ovine Brucellosis (Excluding Brucella ovis).

Rees, R. K., Graves, M., Caton, N., Ely, J. M., Probert, W. S., 2009. single tube identification and strain typing of Brucella melitensis by multiplex PCR. J. Microbial. methods.78:66-70.

Renukaradhya, G. J., Isloor, S. and Rajasekhar, M., 2002. Epidemiology, zoonotic aspects, vaccination and control/eradication of brucellosis in India. Vet. Microbiol, 90(1-4): 183-195.

Shakerian, A., Karim, G., Sharifzadeh, A. and Sadeghy, M., 2013. The Survey on the contamination of ewes fresh white cheese non pasteurized with Brucella mellitensis, Escherichia coli and Staphylococcus aureus in Shahrekord, Iran. Iranian J. Vet. Sci., 2(4): 275-282.

Smits, H. L. and Kadri, S. M., 2005. Brucellosis in India: A deceptive infectious disease. Indian J. Med. Res. 122: $375-384$.

\section{How to cite this article:}

Sumathi, B.R., B.M. Veeregowda, S.M. Byregowda, D. Rathnamma, Shrikrishna Isloor, Rajeswari Shome and Narayanaswamy, H.D. 2019. Molecular Characterization of Brucella melitensis Field Isolates by Bruce- Ladder Multiplex PCR. Int.J.Curr.Microbiol.App.Sci. 8(01): 585-590. doi: https://doi.org/10.20546/ijcmas.2019.801.065 